\title{
Eozinofilik Gastroenterit: Disfaji ile Başvuran Bir Olgu
}

\author{
Eosinophlilic Gastroenteritis: A Case with Dysphagia
}

\section{Uğur Ergün}

Balıkesir Üniversitesi Tip Fakültesi Iç Hastalıkları Anabilim Dalı, Balıkesir

Yazışma Adresi / Correspondence:

Uğur Ergün

Balıkesir Üniversitesi Çağış Yerleşkesi, 10145, Balıkesir

T: +905342109309 E-mail: mdbalkes10@gmail.com

Geliş Tarihi / Received : 01.08.2019 Kabul Tarihi / Accepted : 03.12.2019

Orcid:

Uğur Ergün https://orcid.org/0000-0002-6111-0030

( Sakarya Tip Dergisi / Sakarya Med J 2019, 9(4):721-724) DOI: 10.31832/smj.600027

$\ddot{\mathrm{O} z}$

Eozinofilik gastroenterit, gastrointestinal semptomlara yol açan sindirim kanalının eozinofilik infiltrasyonu ile karakterize nadir görülen bir hastalıktır. Genellikle semptomlar hastalığa özgü değildir. Hastaların çoğunda periferik kanda eozinofil sayısı yüksek bulunmaktadır. Ancak periferik kandaki eozinofil sayısı normal olması hastalığı dışlamadığı gibi tanı ve tedavide gecikmelere neden olmaktadır. Tanıda altın standart histopatolojik incelemedir. Tedavide diyet kısıtlaması, antihistaminikler ve glukokortikosteroid yer almaktadır. Glukokortikosteroid tedavide ana unsurdur ve etkilidir. Bu yazımızda disfaji nedeniyle tarafımıza yönlendirilen ve klinik değerlendirme sonucu eozinofilik gastroenterit tanısı alan olgu sunuldu.

Anahtar disfaji; eozinofilik gastroenterit; glukokortikosteroid

kelimeler

Abstract

Eosinophilic gastroenteritis is a rare disease characterized by eosinophilic infiltration of the digestive tract causing gastrointestinal symptoms. Generally, the symptoms are not disease specific. Most of the patients have high eosinophil count in peripheral blood. However, the normal number of eosinophils in the peripheral blood does not exclude the disease. It causes rare delays in diagnosis and treatment of this disease, which is rarely seen in the background. The definitive diagnosis is made by histopathological examination. There are antihistamines and glucocorticosteroids in the treatment and glucocorticosteroid is the main factor and effective in the treatment. We wanted to present our case who was admitted to our clinic with dysphagia complaint and was diagnosed as eosinophilic gastroenteritis after clinical evaluation.

Keywords dysphagia; eosinophilic gastroenteritis; glucocorticosteroid 


\section{GİRIŞ}

Eozinofilik gastroenterit (EGE), gastrointestinal kanalın farklı bölümlerinin ve katlarının eozinofilik infiltrasyonu ile karakterize hastalığıdır. ${ }^{1}$ Nadir görülen bu hastalığın gerçek insidansı bilinmemektedir. EGE'nin insidansı yaş ile değişmeyip her yaşta ortaya çıkabilir. Erkeklerde kadınlara göre daha sık görülmektedir., ${ }^{2,3}$ Gastrointestinal semptomların varlığı, biyopsi ile gastrointestinal kanalda bir veya daha fazla alanda eozinofilik infiltrasyon gösterilmesi, sindirim sistemi dışında diğer organlarda eozinofilik infiltrasyon ile parazit infeksiyonu olmaması tanıda önemli kriterlerdir. Periferik kanda eozinofili dışında hastalık tanısını düşündüren önemli bir parametre yoktur. Kendine özgü olmayan semptomların olması ya da normal endoskopik görünüme sahip olması hastalığın teşhisinde gecikmelere yol açmaktadır. ${ }^{4}$ Bu makalede disfaji nedeniyle araştırılan ve sonrasında EGE tanısı alan olgu sunuldu.

\section{OLGU SUNUMU}

54 yaşında erkek hasta yutkunma zorluğu şikayeti ile gastroenteroloji polikliniğine başvurdu. Anamnezde disfajinin yaklaşık iki aydır devam ettiği ve özellikle katı gıdalara karşı olduğu öğrenildi. Özgeçmişinde tip 2 diyabetes mellitus dışında bilinen ek bir hastalığı bulunmamaktaydı. Soygeçmişinde de belirgin bir özelliği olmayan hastanın metformin dişında sürekli kullanmakta olduğu ilaç yoktu. Kestane allerjisi olan hastanın sigara ve alkol kullanımı bulunmamaktaydı. Fizik muayenesinde epigastrik hassasiyet dşında ek bir patolojik bulgu saptanmadı. Laboratuvar sonuçlarında hemoglobin (Hgb): $11.3 \mathrm{gr} / \mathrm{dL}$ dışında patolojik bulgu görülmedi (Tablo 1). Diş merkezde çalışılan total immunglobulin E seviyesi 45 IU/L (normal<100 IU/L) olan hastanın özefagogastroduodenoskopi incelemesinde postbulbus kısmında ödematöz ve inflamasyon görünümü hakimdi (Resim 1). Özefagus, antrum ve duodenum bölgelerinden yer yer biyopsi örnekleri alındı. Histopatolojik incelemede duodenum materyaline ait kısmında eozinofilik infiltrasyonu mevcuttu (Resim 2). Paraziter enfestasyon, vaskülopati, kollajen doku hastalıkları ve diğer neoplazi ait patolojik bulgular dışlandı. Hasta eozino- filik gastroduodenit ile uyumlu bulundu. Kemik mineral dansitometre sonucu normal olan hastaya günlük $20 \mathrm{mg}$ prednizolon tedavisi başlandı. Prednizolon tedavisi 6 hafta boyunca devam edildi ve doz azaltımı uygulanarak ilaç kesildi. Tedavi sonrası klinik durumunda iyileşme izlenen hastanın kontrol muayanelerinde nüks görülmedi. Makalenin yayımlanması ve gerekli materyallerinin kullanımı konusunda hastadan bilgilendirilmiş onam formu alındı.

\begin{tabular}{|c|c|c|c|c|c|}
\hline HGB & $11,3 \mathrm{~g} / \mathrm{dL}$ & $\mathrm{Ca}$ & $\begin{array}{c}9.2 \mathrm{mg} / \\
\mathrm{dL}\end{array}$ & INR & 1,08 \\
\hline MCV & $80 \mathrm{fL}$ & AST & $17 \mathrm{U} / \mathrm{L}$ & CRP & $\begin{array}{l}<3.02 \\
\mathrm{mg} / \mathrm{L}\end{array}$ \\
\hline WBC & $\begin{array}{c}10.100 / \\
\mathrm{mm} 3\end{array}$ & ALT & $13 \mathrm{U} / \mathrm{L}$ & Sedimentasyon & $\begin{array}{c}8 \mathrm{~mm} / \\
\text { saat }\end{array}$ \\
\hline PLT & $\begin{array}{c}208.000 / \\
\mathrm{mm} 3\end{array}$ & ALP & $80 \mathrm{U} / \mathrm{L}$ & $\mathrm{RF}$ & negatif \\
\hline ÜRE & $25 \mathrm{mg} / \mathrm{dL}$ & GGT & $48 \mathrm{U} / \mathrm{L}$ & ANA & negatif \\
\hline $\mathrm{Cr}$ & $\begin{array}{c}0.7 \mathrm{mg} / \\
\mathrm{dL}\end{array}$ & Amilaz & $28 \mathrm{U} / \mathrm{L}$ & C-ANCA & negatif \\
\hline $\mathrm{Na}$ & $\begin{array}{c}139 \\
\mathrm{mEq} / \mathrm{L}\end{array}$ & Albümin & $4.7 \mathrm{~g} / \mathrm{dL}$ & P-ANCA & negatif \\
\hline K & $\begin{array}{c}4,3 \\
\mathrm{mEq} / \mathrm{L}\end{array}$ & Ferritin & $10 \mathrm{ng} / \mathrm{mL}$ & AntidsDNA & negatif \\
\hline \multicolumn{6}{|c|}{$\begin{array}{l}\text { HGB: Hemoglobin, MCV: Ortalama corpuscular hacim, WBC: Lökosit, PLT: Platelet, } \\
\text { Cr: Kreatinin, Na: Sodyum, K: Potasyum, Ca: Kalsiyum, AST: Aspartat aminotransferaz, } \\
\text { ALT: Alanin aminotransferaz, GGT: Gama glutamil transferaz, ALP: Alkalen fosfataz, } \\
\text { INR: Uluslararası standardize oran, CRP:C reaktif protein, RF: Romatoid faktör, ANA: } \\
\text { Antinükleer antikor, C-ANCA: Antinötrofil sitoplazmik antikor, P-ANCA: Perinüklear } \\
\text { antinötrofil sitoplazmik antikor, AntidsDNA: Çift standart DNA antikor }\end{array}$} \\
\hline
\end{tabular}

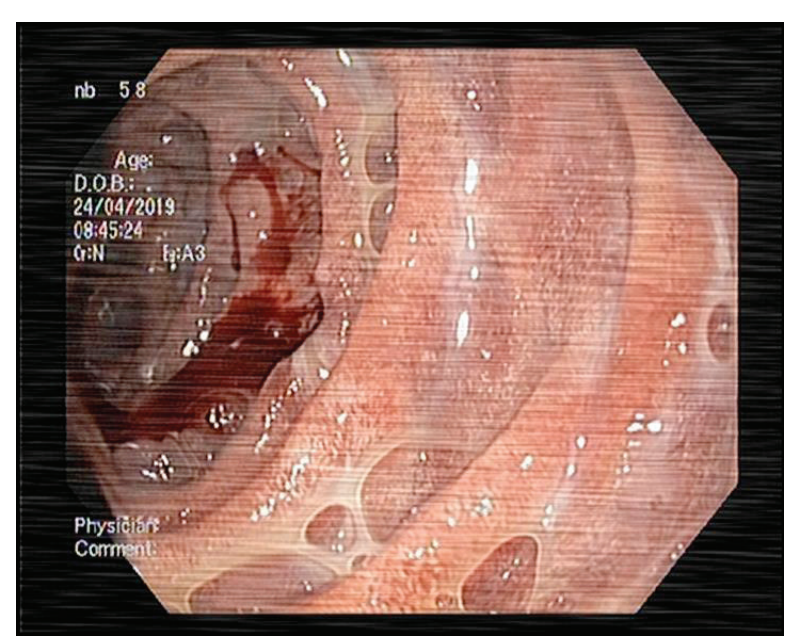

Resim 1. Özefagogastroduodenoskopi incelemesi, duodenum 2.kısım, ödematöz ve eksudatif değişiklikler. 


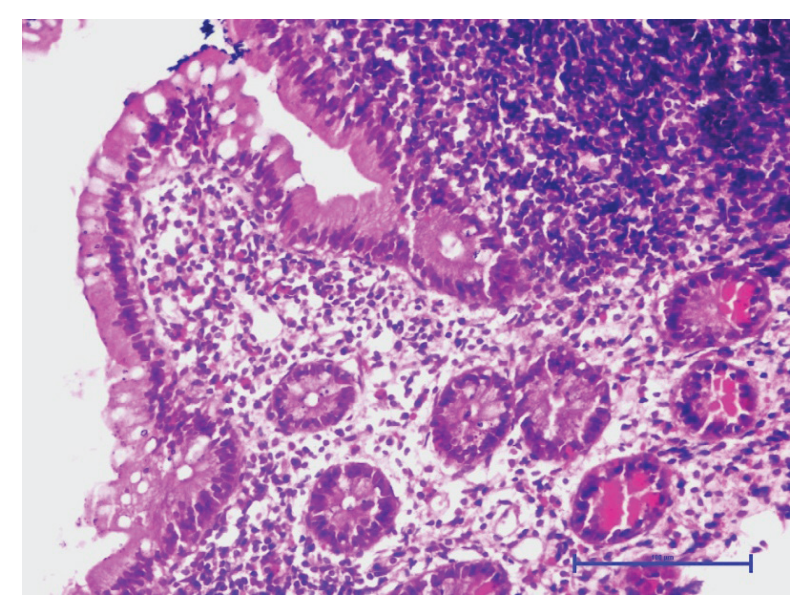

Resim 2. Doudenum biyopsi materyaline ait histopatolojik kesitlerdeki glandlar arasındaki yaygın eozinofilik infiltrasyon (H\&E x 100).

\section{TARTIŞMA}

EGE, gastrointestinal kanalın farklı bölümlerinin ve katlarının eozinofilik infiltrasyonu ile karakterize hastalıktır. ${ }^{4}$ Nadir gözlenen hastalık olup çeşitli semptomlar ile karşımıza çıkabilmektedir. Tanısı gastrointestinal semptomların varlığı, biyopsi ile gastrointestinal kanalda bir veya daha fazla alanda eozinofilik infiltrasyon gösterilmesi, gastrointestinal kanal dışında başka organlarda eozinofilik infiltrasyon bulunmamas1, parazit enfestasyonu olmamasına göre belirlenmiştir. ${ }^{5,6}$ EGE, en sık mide ve ince barsak kısmında görülmekte olup gastrointestinal sistem kanalına ait her kısmı tutabilir. Çoğu olguda periferik kanda eozinofil sayısının yüksek saptandığı gibi bazı vakalarda normal sonuçlanabilir. ${ }^{7}$ Olgumuzun periferik kanında eozinofili olmaması bu konuda dikkat çekici noktadır. Ay1rıcı tanıda parazit enfestasyonunu dışlanması için gaita tetkikleri yapılmalıdır. Bu açıdan olgumuzun serolojik ve koproparazitolojik test incelemeleri negatifti. Aynı zamanda endoskopik inceleme ile alınan biyopsi materyallerine ait histopatolojik çalışmada eozinofil kümelerinin submukoza, musküler tabaka ve serozada bulunması veya kriptlerin içine göç etmesi tanıı destekleyen bulgulardır.?
Konnektif doku hastalıklarından skleroderma, dermatomiyozitis ve polimiyozitiste, vaskülitlerde, allerjik anjitis ve granülamatoziste, poliarteritis nodozada gastrointestinal kanalın eozinofilik infiltrasyonu görülebilir. Ayırıcı tanı hipereozinofilik sendrom ve sistemik mastositoz ile de yapılmalıdır. Zaman zaman multisistem hastalıklar barsak tutulumuna yol açabilir ve EGE ile karışabilir. ${ }^{8,9} \mathrm{Ol}$ gumuzda gastrointestinal kanal dışında eozinofilik infiltrasyon yapabilecek organik patoloji saptamadi. Tedavide diyet kısitlaması, antihistaminik, sodyum kromoglikat ve glukokortikosteroid yer almaktadır. Aynı zamanda tüm hastalarda semptom ve gıda ilişkisi sorgulanmalı, şüpheli gıdalar diyetten çıkarılmalıdır. Nüks vakalarda veya obstrüktif semptomları olan hastalarda glukokortikosteroid tedavisi 20-40 mg/gün olarak başlanabilir. Hastalık bazen remisyon ve ataklar halinde ortaya çıabilmektedir. $\mathrm{Bu}$ hastalarda remisyonu devam ettirebilmek için yüksek doz kortikosteroid tedavisine ihtiyaç duyulabilmektedir. ${ }^{8}$

Sonuç olarak, EGE, kendine özgü olmayan semptom ve bulgularla karşımıza çıkan son derece nadir görülen bir hastalıktır. Periferik kanda eozinofili saptanması önemli bir parametre ancak normal olması hastalığı dışlamamaktadır. Çoğu vakada atopik öykü bulunmaktadır. Çoğu kez tanı ve tedavide gecikmeler yaşanmaktadır. Ayırıcı tanılar arasında önemli bir yeri olduğunu düşünüyoruz. Olgumuzun steroid tedavisine çok iyi yanıt verdiği ve takiplerinde nüks olmadığı görülmüştür. 
Sakarya Tip Dergisi 2019;9(4):721-724

UĞUR ERGÜN Eozinofilik Gastroenterit: Disfaji ile Bașvuran Bir Olgu

\section{Kaynaklar}

1. Talley NJ. Eosinophilic Gastroenteritis. In Gastrointestinal and Liver disease. (Ed) Feldman M, Friedman LS, Sleisenger MH.WB Saunders Company, Philadelphia 2002; 1972-82.

2. Dursun M, Yılmaz Ș, Canoruç F, Sarı Y. Eozinofilik gastroenterit: assit ile bașvuran bir vaka. Turkiye Klinikleri Gastroenterohepatoloji Dergisi 2003;14(2):195-7.

3. Guajardo JR, Plotnick LM, Fende JM, et al. Eosinophil-associated gastrointestinal disorders: a world-wide-web based registry. J Pediatr 2002; 141:576-81.

4. Bolukbas FF, Bolukbas C, Uzunkoy A, Baba F, Horoz M, Öztürk G. A dramatic response to ketotifen in case of eosinophilic gastroenteritis mimicking abdominal emergency. Dig Dis Sci 2004;49(12):1782-5.

5. Erdem L, Akbayir N, Yildirim S, Koksal HM, Yenice N, Gultekin OS, et al. [Predictive value of morphologic characteristics in rectosigmoid adenomatous polyps for the probability of synchronous polyps or cancer in the proximal colon]. Turk J Gastroenterol 2005;16(4):207-11.
6. Uzunismail H. [Eosinophilic gastroenteritis]. Endoscopy Journal 2000;11(4):34-8.

7. Brandwein SL, Fridman LS. Eosinophilic gastroenteritis. In: Brandt LJ, Daum F, eds. Clinical Practice of Gastroenterology. 1st ed. Philadelphia: Current Medicine Inc; 1999. p.557-70.

8. Fox VL, Nurko S, Teitelbaum JE, et al. High resolution EUS in children with eosinophilic esophagitis. Gastrointest Endosc 2003; 57:30-6.

9. Ravi K, Talley NJ, Smyrk TC, et al. Low grade esophageal eosinophilia in adults: an unrecognized part of the spectrum of eosinophilic esophagitis? Dig Dis Sci 2011; 56:1981-6. 